\title{
Electrical Conduction and Reaction Analysis on Mixed-Conducting Iron-Doped Barium Zirconate
}

\author{
Haomiao Zhang and Benjamin A. Wilhite* \\ Artie McFerrin Department of Chemical Engineering \\ Dwight Look College of Engineering \\ Texas A\&M University \\ College Station, TX 77845
}

*author to whom correspondence should be addressed. Email: benjaminwilhite@tamu.edu 


\begin{abstract}
Mixed conducting $\mathrm{BaZr}_{0.9} \mathrm{Fe}_{0.1} \mathrm{O}_{3-\delta}$ perovskite (BZF10) was experimentally investigated in terms of electrochemical, catalytic and material characterization over a cycle of dry $\mathrm{CO}_{2}$, humidified Ar, $\mathrm{CO}$ and $\mathrm{H}_{2}$ for SOEC or SORFC operation. BZF10 exhibited both mixed ionicelectronic conduction under oxidizing conditions and mixed protonic-electronic conduction under humidified reducing conditions. Upon exposure to dry $\mathrm{CO}_{2}$ atmosphere, the material shows catalytic activity towards $\mathrm{CO}_{2}$ reduction which is attributed to an intermediate carbonate ion formation on the cell surface. Exposure to moisture under inert gas environment suggests only mild interaction with steam; however, under moist $\mathrm{CO}$ environment a complex conduction mechanism is displayed alongside significant rates of water-gas-shift while exposure to humidified $\mathrm{H}_{2}$ indicates n-type semi-conduction. Upon completion of $>1,000$ hours of continuous exposure to a range of oxidizing and reducing gas environments, physical inspection of the BZF10 electrochemical cell indicated negligible chemical or mechanical degradation, while XRD indicates retention of high perovskite phase purity with significant Fe segregation to the intergranular region confirmed via XEDS elemental mapping.
\end{abstract}

Keywords: $\mathrm{Ba}_{0.90} \mathrm{Zr}_{0.90} \mathrm{Fe}_{0.10} \mathrm{O}_{3-\delta}(\mathrm{BZF} 10)$; Electroceramics; Mixed Conductor; $\mathrm{CO}_{2}$ mitigation; Electrical Conduction; Reaction Analysis 


\section{Introduction}

Catalytic electroceramics promise multiple potentially transformative solutions to a broad range of environmental and energy challenges in the $21^{\text {st }}$ century [1-5]. Oxygen-conducting membranes employing mixed ionic-electronic conducting (MIEC) materials enable oxygen separation from air in support of clean combustion [6-7], or selective oxygen coupling with light hydrocarbons for enhanced utilization of natural gas and refinery gases [8-9]. In recent years, solid-oxide electrolysis cells (SOECs) employing catalytic MIEC electrodes capable of converting waste heat, $\mathrm{H}_{2} \mathrm{O}$ and $\mathrm{CO}_{2}$ from combustion processes into syn-gas (a mixture of $\mathrm{CO}$ and $\mathrm{H}_{2}$ ) have been investigated as a novel means of producing synthetic fuels or petrochemicals while minimizing greenhouse gas (GHG) emissions [10-12]. Solid oxide reversible fuel cells (SORFCs) utilizing catalytically active MIEC materials support the large-scale storage of electrical energy generated by inherently transient and $\mathrm{CO}_{2}$-free renewable energy sources such as wind, solar and tidal energy harvesting by providing a means to chemically store excess electrical energy by via reduction of $\mathrm{CO}_{2}$ to $\mathrm{CO}$, with subsequent electrical power generation via $\mathrm{CO}$ electrochemical oxidation at high efficiencies during peak power loads or low power generation periods [13-16]. SOECs have also received significant recent interest due to their ability to generate $\mathrm{H}_{2}$ through electrolysis of $\mathrm{H}_{2} \mathrm{O}$ at greater energy efficiencies than photocatalytic or thermochemical water splitting techniques [17-19]. The $\mathrm{H}_{2}$ produced can be utilized as an alternative fuel convertible to electrical energy by fuel cells at competitive efficiencies with zero emissions at the point-of-use [20-21].

SOEC and SORFC development largely relies upon the discovery of inherently multifunctional materials capable of providing the requisite catalytic and electrochemical properties while retaining material and mechanical stability under harsh reducing environments uncommon 
to traditional SOFC cathodes. Specifically, there is a need to significantly improve SORFC efficiency and stability under both $\mathrm{CO}$-oxidation and $\mathrm{CO}_{2}$-reduction conditions. Recent research has focused on catalytic transition metal dopants to achieve new combinations of catalytic, ionic and electronic properties [22-23]. Currently reported high-performance MIEC materials including $\mathrm{La}_{\mathrm{x}} \mathrm{Sr}_{1-\mathrm{x}} \mathrm{MnO}_{3+\mathrm{x}}(\mathrm{LSMO}), \mathrm{La}_{\mathrm{x}} \mathrm{Sr}_{1-\mathrm{x}} \mathrm{Co}_{\mathrm{y}} \mathrm{Fe}_{1-\mathrm{y}} \mathrm{O}_{3+\mathrm{x}}$ (LSCF) are capable of combining competitive oxygen-ion and electrical conductivities with high stability under oxidizing conditions, making them excellent candidates for SOFC cathodes [24-27]. However, the stability of these A-site doped MIECs under reducing atmospheres limits their viability in SOEC or oxygen-conducting membrane reactor applications [28-29]. The authors have previously demonstrated Co-doped $\mathrm{Ba}\left(\mathrm{Ce}_{\mathrm{y}} \mathrm{Zr}_{1-\mathrm{y}}\right) \mathrm{O}_{3}$ to be an attractive electroceramic catalyst with mixed ionic-electronic conducting properties suitable for clean energy application [30]; however the stability of this material against hydrolysis degradation under humid reducing environments was found to be poor, as attributed to the low reduction potential of Co dopant and susceptibility of Ce to incorporate hydroxyl ions - both of which enable rapid degradation via Ba hydrolysis [31]. For these reasons, our recent research has focused upon investigating $\mathrm{Fe}$-doped $\mathrm{BaZrO}_{3}[32]$

Fe-based catalysts have established catalytic surface activities for syn-gas production and Fischer-Tropsch synthesis of hydrocarbons [33-36], while Fe oxide catalysts are known to preferentially chemisorb $\mathrm{CO}_{2}$ via formation of surface $\mathrm{CO}_{3}{ }^{2-}$ groups via reaction with available $\mathrm{O}^{2-}$ ions [37-38]. In addition, Fe-doped materials were demonstrated to display higher stability under reducing atmosphere at high temperatures typical of fuel cell or oxygen permeation membrane conditions. Fe-doped $\mathrm{La}_{x} \mathrm{Sr}_{1-\mathrm{x}} \mathrm{TiO}_{3}$ was shown by Fagg et al. to have high stability and mixed conductivity suitable for potential SOFC anode materials [39] while high oxygen permeation rates combined with high materials stability against reduction were demonstrated for 
Fe-doped $\mathrm{LaGaO}_{3}$ [40]. The authors' recent findings confirmed high material stability under oxidizing atmospheres with promising oxygen permeability between $600-800^{\circ} \mathrm{C}$ for Fe-doped $\mathrm{BaZrO}_{3}$. In this manuscript, we report the investigation of Fe-doped $\mathrm{BaZrO}_{3}$ over a full cycle of oxidizing and reducing environments expected for both SOEC and SORFC applications. Specifically, we report the electrochemical and catalytic behavior of Fe-doped $\mathrm{BaZrO}_{3}$ under dry $\mathrm{CO}_{2}$, humidified inert $\mathrm{Ar}, \mathrm{CO}$ and $\mathrm{H}_{2}$ environments followed by detailed materials analysis of the as-exposed material to assess the final, stable reduced perovskite microstructure and composition. Results thus provide valuable insight into the underlying electrochemical mechanisms present as well as the long-term materials stability of acceptor-doped perovskites under both oxidizing and reducing environments.

\section{Experimental}

\subsection{Electrochemical characterization coupled with reaction study}

Fe-doped $\mathrm{BaZrO}_{3}$ perovskites powders were synthesized via solid-state reaction using precursor nitrate powders to target a final composition of $\mathrm{BaZr}_{0.9} \mathrm{Fe}_{0.1} \mathrm{O}_{3-\delta}$ referred to for the remainder of the manuscript as BZF10, and subsequently fabricated into $13 \mathrm{~mm}$ diameter dense pellets. Previously reported [32] analysis of the as-synthesized powders confirmed a final perovskite composition of $\mathrm{Ba}_{0.90} \mathrm{Zr}_{0.90} \mathrm{Fe}_{0.10} \mathrm{O}_{3-\delta}$. A detailed report of the powder synthesis technique, pellet fabrication process, material characterization using synchrotron XRD, TEM, STEM-XEDS, etc. and electrochemical analysis under dry $\mathrm{O}_{2} / \mathrm{Ar}$ atmosphere at $600-800^{\circ} \mathrm{C}$ of BZF10 can be found in our previous publication. [32] The $13 \mathrm{~mm}$ diameter, $0.72 \mathrm{~mm}$ thick cylindrical button cell was prepared with a porous Pt electrode annealed on one face and a dense 
Pt blocking electrode adhered on the other prior to placement within a quartz-ceramic tube-intube single-chamber assembly (Figure 1), and continuously investigated via combined electrochemical and catalytic experiments over the sequence of oxidizing and reducing environments detailed below. The single-chamber apparatus provides continuous gas flow over the cell surface while enabling electrical connections to porous and blocking electrodes. Both electrodes were connected via coaxial cables to a frequency response analyzer (Solartron, SI 1260) and potentiostat (Solartron, SI 1287) operated by CorrWare and Zplot software to perform electrical conductivity relaxation (ECR) and electrochemical impedance spectroscopy (EIS) analysis, respectively. A gas mixing panel equipped with digital mass flow meters (Alicat Scientific Inc.) allowed precise blending of feed gases to achieve target partial pressures within the chamber. A temperature-controlled bubbler filled with de-ionized water was used to introduce steam at variable steam partial pressure for analysis under humidified inert (Ar) and reducing $\left(\mathrm{CO}\right.$ or $\left.\mathrm{H}_{2}\right)$ gases. Effluent gases passed through a liquid trap filled with dry ice to remove moisture prior to gas analysis via quadropole mass spectrometer (QMS) (RGA 100, Stanford Research Systems). The QMS was calibrated using a "five-point" external standard technique for each gas species of interest $\left(\mathrm{O}_{2}, \mathrm{CO}_{2}, \mathrm{CO}, \mathrm{CH}_{4}, \mathrm{H}_{2}\right.$ and $\left.\mathrm{Ar}\right)$ prior to experiments and recalibrated upon completion of all gas exposures.

The single-chamber assembly was inserted into a programmed tube-furnace (Carbolite, MTF $10 / 25 / 130$ ) and heated to $800^{\circ} \mathrm{C}$ at a rate of $3^{\circ} \mathrm{C} / \mathrm{min}$ under $100 \mathrm{~cm}^{3} / \mathrm{min}$ dry Ar flow. Dry $\mathrm{O}_{2} / \mathrm{Ar}$ was first introduced into the electrochemical cell at $800^{\circ} \mathrm{C}$ and subsequently at $50^{\circ} \mathrm{C}$ intervals down to $600^{\circ} \mathrm{C}$. [32] After the electrochemical characterization under dry $\mathrm{O}_{2} / \mathrm{Ar}$, a 24hours dry Ar washing $\left(100 \mathrm{~cm}^{3} / \mathrm{min}\right)$ at $600^{\circ} \mathrm{C}$ was employed to blow away all the $\mathrm{O}_{2}$ remaining in the system and bring the cell back to the fresh as-sintered state to initialize the subsequent $\mathrm{CO}_{2}$ 
gas exposure analysis. At this point, the combined electrochemical and catalytic investigations of the BZF10 material were performed as follows. Upon equilibration of the electrochemical cell with Ar, the assembly was heated to $800^{\circ} \mathrm{C}$ at a rate of $3^{\circ} \mathrm{C} / \mathrm{min}$. Once at temperature, the material was exposed to a sequence of step-changes in $\mathrm{CO}_{2}$ partial pressure $\left(p \mathrm{CO}_{2}=0.01,0.025\right.$, $0.05,0.075,0.10 \mathrm{~atm})$ in dry gas conditions and the $\mathrm{CO}_{2}$ stream was diluted in Ar maintaining a total flowrate of $100 \mathrm{~mL} / \mathrm{cm}^{3}$. After each step-change in gas composition, the transient response in electrical conductivity was measured using a two-point technique with an excitation current of $10 \mathrm{~mA}$ and recorded with time until equilibration of the material with the new gas environment was reached. Once the measured electrical conductivity stabilized, a sequence of five impedance spectra was obtained over the frequency range of $1 \mathrm{MHz}$ down to $0.1 \mathrm{~Hz}$ (amplitude $\sim 10 \mathrm{mV}$ ). Based upon an assumed equivalent circuit [32], the resulting Nyquist plots allow determination of bulk material resistance from the left-most x-intercept and provide insight into grain boundary resistance through the middle semi-circle and surface kinetics based upon the right-most tail/semi-circle. After the dry $\mathrm{CO}_{2} / \mathrm{Ar}$ exposure, the same dry Ar washing procedure was employed to blow away all the carbon containing gases in the material and also recalled when finishing other gases $\left(\mathrm{H}_{2} \mathrm{O}, \mathrm{CO}, \mathrm{H}_{2}\right)$ exposure test. Following the same procedure, the electrochemical cell was exposed to a sequence of step-changes in steam partial pressure $\left(\mathrm{pH}_{2} \mathrm{O}\right.$ $=0.021,0.042,0.073,0.12,0.20 \mathrm{~atm}), \mathrm{CO}$ partial pressure in humidified condition through steam bubbler $(p C O=0.01,0.025,0.05,0.075,0.10 \mathrm{~atm})$ and $\mathrm{H}_{2}$ partial pressure in humidified condition through steam bubbler $\left(\mathrm{pH}_{2}=0.025,0.05,0.10,0.15,0.20 \mathrm{~atm}\right)$. For humidified gases tests, the steam bubbler temperature was set at room temperature $\left(19^{\circ} \mathrm{C}\right)$ followed by $30,40,50$, $60{ }^{\circ} \mathrm{C}$ for $\mathrm{H}_{2} \mathrm{O}$ exposure tests under inert (Ar) atmosphere and remained fixed at room temperature $\left(19^{\circ} \mathrm{C}\right)$ for all subsequent $\mathrm{CO}, \mathrm{H}_{2}$ exposures. 


\subsection{Materials analysis of as-used BZF10 pellet}

Upon completion of all gas exposure tests, a portion of the pellet was ground into powder and characterized by synchrotron X-ray diffraction analysis using a scan rate of $0.6^{\circ} / \mathrm{min}$ and $0.5^{\circ}$ $\leq 2 \theta \leq 50^{\circ}$ scan range, at Advanced Photon Source, Argonne National Lab (IL, USA).

Microscopy analysis of a fracture cross-section of the as-used BZF10 pellet and its chemical maps were investigated by transmission and scanning transmission electron microscopy (TEM \& STEM) coupled with energy dispersive X-ray spectroscopy (XEDS). Cross-section TEM specimens were prepared by manual grinding and thinning of fractured samples, followed by dimpling and subsequent ion milling (PIPS 691 ion polishing system, $3.7 \mathrm{keV}$ ) to achieve suitably thin (electron-transparent) specimens. A TEM (FEI Tecnai G2 F20 ST microscope with a point resolution of $0.24 \mathrm{~nm}$ ) operated at $200 \mathrm{kV}$ and a TEM-STEM attachment of the same microscope operated at $200 \mathrm{kV}$ were used for conventional and analytical imaging of the sample, respectively.

\section{Results}

\subsection{Electrochemical characterization coupled with reaction study}

\subsubsection{Dry $\mathrm{CO}_{2}$}

Figure 2a-b present the EIS results in the form of Nyquist plots obtained under dry $\mathrm{CO}_{2} /$ Ar environment at $800^{\circ} \mathrm{C}$ and $600^{\circ} \mathrm{C}$, respectively. At $800^{\circ} \mathrm{C}$, the Nyquist plots started with a high-frequency tail, which was located in the positive imaginary resistance zone and attributed to inductance, continued with a mid-frequency arc indicating grain boundary conduction and 
ended with a low-frequency tail suggesting the presence of surface reactions that influence bulk electrical conductivity. EIS data obtained at $800^{\circ} \mathrm{C}$ indicate increasing grain resistances at higher $\mathrm{CO}_{2}$ partial pressure $\left(p C \mathrm{O}_{2}\right)$ and the presence of surface reaction at all $\mathrm{CO}_{2}$ partial pressures. EIS data obtained at $600^{\circ} \mathrm{C}$ likewise consist of a high-frequency arc located fully within the negative imaginary resistance zone, which was attributed to grain boundary transport and a low-frequency tail indicating the presence of surface reaction mechanism as that at $800^{\circ} \mathrm{C}$. In contrast to the trend observed at $800^{\circ} \mathrm{C}$, Nyquist plots at $600^{\circ} \mathrm{C}$ indicate higher grain boundary resistances at low $\mathrm{pCO}_{2}$, suggesting a different semi-conduction mechanism from that at $800^{\circ} \mathrm{C}$.

Figure $2 \mathrm{c}$ presents the total electrical conductivity as a function of $\mathrm{pCO}_{2}$ on a $\log -\log$ plot. Consistent with the p-type semi-conduction mechanism described in our previous paper under dry $\mathrm{O}_{2}$ environment [32], an increase in electrical conductivity resulting from $\mathrm{CO}_{2}$ introduction via similar reaction of oxidizing gas with oxygen vacancies would be expected (Reaction 1), where subscript "s" and "g" denote surface and gaseous species, respectively, and the describing all other species using Kröger-Vink notation [41].

$$
C O_{2(g)}+V_{O}^{\bullet \bullet} \leftrightarrow C O_{(g)}+O_{O}^{X}+2 h^{\bullet}
$$

However, at $650-800^{\circ} \mathrm{C}$, the electrical conductivity is found to decrease with increasing $\mathrm{pCO}_{2}$ when introducing dry $\mathrm{CO}_{2} / \mathrm{Ar}$ to the electrochemical cell, which indicates that Reaction 1 fails to describe the electrochemical reaction at high $\mathrm{pCO}_{2}$. An alternative mechanism (Reaction 2) explains this electrochemical behavior by assuming that $\mathrm{CO}_{2}$ first reacts with surface lattice oxygen $\left(O_{O}^{X}\right)$ to generate surface carbonate ion $\left(\mathrm{CO}_{3}^{2-}{ }_{(s)}\right)$ and oxygen vacancies $\left(V_{o}^{\bullet \bullet}\right)$, followed by the subsequent decomposition of $\mathrm{CO}_{3}^{2-}$ (s) to produce $\mathrm{CO}$ and $\mathrm{O}_{2}$ (Reaction 3). 


$$
\begin{gathered}
\mathrm{CO}_{2(g)}+\mathrm{O}_{O}^{X} \leftrightarrow \mathrm{CO}_{3}^{2-}(s) \\
+V_{O}^{\bullet \bullet} \\
\mathrm{CO}_{3_{(s)}^{2-}}+2 h^{\bullet} \leftrightarrow C O_{(g)}+O_{2(g)}
\end{gathered}
$$

The assumption of an intermediate carbonate ion formation at the BZF10 surface is supported by multiple literature reports of ion formation on both Fe-based oxide catalyst [37-38] and mixed conducting ceramic membrane surfaces [42-43]. The overall reaction (Reaction 2+3) thus consists of molecular $\mathrm{CO}_{2}$ being incorporated by surface lattice oxygen and two electron holes to release molecular $\mathrm{CO}$ and $\mathrm{O}_{2}$ while leaving behind a mobile oxygen vacancy, which describes the observed decrease in electrical conductivity with increasing $p \mathrm{CO}_{2}$. Additional mathematical proof is presented in Appendix A.

$$
C O_{2(g)}+O_{O}^{X}+2 h^{\bullet} \leftrightarrow V_{O}^{\bullet \bullet}+C O_{(g)}+O_{2(g)}
$$

Figure $2 \mathrm{~d}$ presents the total electrical conductivity as a function of temperature on a semi$\log$ plot. The related activation energy is calculated to be $0.44-0.70 \mathrm{eV}$, which decreases with increasing $\mathrm{pCO}_{2}$ becoming significantly larger than that associated with the dry $\mathrm{O}_{2} / \mathrm{Ar}$ exposure (0.16-0.18 eV). These higher activation energies support the above argument of a different semiconduction mechanism from that under dry $\mathrm{O}_{2}$ exposure. Additionally, the electrical conductivity of the BZF10 material reduced from $16.4 \mathrm{mS} \cdot \mathrm{cm}^{-1}$ to $1.6 \mathrm{mS} \cdot \mathrm{cm}^{-1}$ after exposure to $\mathrm{CO}_{2}$, suggesting an initial net reduction of BZF10 material via Reaction 1, before Reactions $2+3$ come to dominate the electrochemical response. The expected oxygen vacancy sites are $2.93 \times 10^{-4} \mathrm{~mol}$ within the material, and the steady-state $\mathrm{CO}$ production confirmed by QMS measurement of CO levels in effluent gas (Figure 2e) can be up to $1.25 \times 10^{-3}$ mol (each experiment duration is 1 hour), thus a steady-state catalytic reaction rather than a transient respond is confirmed. The 
presence of steady-state surface suggests first-order kinetics with respect to $\mathrm{pCO}_{2}$ at both high and low $\mathrm{pCO}_{2} \mathrm{~S}$ with maximum reaction rate of $3.06 \times 10^{-3} \mathrm{~mol} \cdot \mathrm{s}^{-1} \cdot \mathrm{m}^{-2}$ at 0.1 atm $p \mathrm{CO}_{2}$ and $800^{\circ} \mathrm{C}$.

\subsection{2 $\mathrm{H}_{2} \mathrm{O}$}

Figure 3 a presents the Nyquist plots obtained under $\mathrm{H}_{2} \mathrm{O} / \mathrm{Ar}$ environment at $800^{\circ} \mathrm{C}$ and $600^{\circ} \mathrm{C}$. At both temperatures, the Nyquist plots started with a high-frequency inductive tail, continued with a small semi-circle indicating finite grain boundary resistance and a short lowfrequency tail suggesting negligible surface reaction. EIS data indicates the material is less active at a lower temperature, while the similar shape of Nyquist plots suggests an identical mechanism between $600-800^{\circ} \mathrm{C}$.

Log-log plots of electrical conductivity versus $\mathrm{H}_{2} \mathrm{O}$ partial pressure $\left(\mathrm{pH}_{2} \mathrm{O}\right)$ presented in Figure $3 \mathrm{~b}$ indicate a slight decrease in total conductivity $(\Delta \sigma<0.7 \%)$ with increasing $\mathrm{pH}_{2} \mathrm{O}$, corresponding to an order dependency of -0.02 at $800^{\circ} \mathrm{C}$ and $\sim 0$ at $600-750^{\circ} \mathrm{C}$. The zero slope suggests only slight decrease in mobile charge carrier concentrations occurring within the cell. The related activation energy is calculated to be $0.23 \mathrm{eV}$ (Figure 3c), which is found to be invariant with steam partial pressure. Negligible conversion of steam to oxygen and hydrogen or reactions with any possible remainder carbonaceous species from previous dry $\mathrm{CO}_{2}$ exposure was verified by the QMS results, which showed $<500 \mathrm{ppm} \mathrm{H}_{2}, \mathrm{O}_{2}, \mathrm{CO}, \mathrm{CO}_{2}$ and $\mathrm{CH}_{4}$ contents existing in the dry effluent.

The calculated oxygen vacancy diffusion coefficients $D_{V}$ of BZF10 are in the range of $10^{-}$ ${ }^{8}-10^{-7} \mathrm{~m}^{2} / \mathrm{s}$ from $600-800^{\circ} \mathrm{C}$. [32] It gives a diffusion time of $2.6-26$ seconds across the thickness of the button cell, which is much smaller than the duration of experiment (1 hour), 
indicating the electrical conductivity change is not limited by bulk diffusion. Under exposing to $\mathrm{H}_{2} \mathrm{O} / \mathrm{Ar}$, Fe ions were difficult to be largely reduced, otherwise a subsequent obvious change in electronic conductivity would be expected. Thus the slight decrease in electrical conductivity may be explained by protonic charge carrier uptake via electrochemical reaction of an $\mathrm{H}_{2} \mathrm{O}$ molecule splitting a proton combining with a surface lattice oxygen atom and a hydroxyl ion occupying an oxygen vacancy site to generate two hydroxyl ions $\left(\mathrm{OH}_{O}^{\bullet}\right)$ via Reaction 5,

$$
\mathrm{H}_{2} \mathrm{O}+\mathrm{V}_{O}^{\bullet \bullet}+\mathrm{O}_{O}^{X} \leftrightarrow 2 O H_{O}^{\bullet}
$$

assuming that the resulting hydroxyl ions are slightly less mobile than oxygen vacancies at 600$800^{\circ} \mathrm{C}$. Reaction 5 , a commonly verified mechanism for acceptor-doped perovskites [44-46], suggests the presence of proton conduction; however the observed $\sim 0$ slope at $600-800^{\circ} \mathrm{C}$ implies either minimal surface electrochemical reaction, or the increase of proton conductivity by water incorporation and the increase of electronic conductivity by reduction of Fe ions compensating the decrease of conductivity caused by the consumption of mobile oxygen vacancies in the absence of reducing gas species i.e., $\left(\Delta \sigma_{O H_{o}^{*}} \approx \Delta \sigma_{V_{o}^{*}}\right)$.

\subsubsection{Humidified CO}

Nyquist plots obtained in the presence of humidified CO/Ar reducing gas at $800^{\circ} \mathrm{C}$ (Figure 4a) show two primary shapes under different $\mathrm{CO}$ partial pressure $(p C O)$. When $\mathrm{CO} / \mathrm{H}_{2} \mathrm{O}$ was first introduced into the electrochemical cell $(p C O \rightarrow 0.01 \mathrm{~atm})$, the resulting Nyquist plot started with a flattened semi-circle at high resistance followed by a short tail suggesting significant grain boundary resistance and mild surface reaction rates. With increasing $p C O$, the 
resistance was reduced while high-frequency inductive tail remained and grain boundary transport reduced significantly. At $600^{\circ} \mathrm{C}$, the inductive tail completely disappears from the Nyquist plots (Figure 4b). All plots display a high-frequency semi-circle and a low-frequency tail, both of which are consistent with the shape obtained at $0.01 \mathrm{~atm} p C O$ and $800^{\circ} \mathrm{C}$.

Log-log plots of electrical conductivity as a function of $\mathrm{CO}$ partial pressure present two distinct regions corresponding to low ( $\leq 0.05 \mathrm{~atm})$ and high $(\geq 0.05 \mathrm{~atm}) p C O$ at $600-800^{\circ} \mathrm{C}$. In the low $p C O$ region, a positive dependence approaching $1 / 2$-order was observed at $800^{\circ} \mathrm{C}$ (Figure 4c) which decreased to 0.04 at $600^{\circ} \mathrm{C}$, suggesting that temperature is the rate limiting factor at $600^{\circ} \mathrm{C}$, not the reagent concentration. The related activation energies (Figure $4 \mathrm{~d}$ ) are 0.48-0.78 $\mathrm{eV}$, which increase with $p C O$. Conductivity under humidified $\mathrm{CO} / \mathrm{Ar}$ environment is lower than that under humidified inert. However, at high $p C O$ the observed negative dependence varied from -1 -order at $800^{\circ} \mathrm{C}$ to -0.5 -order at $600^{\circ} \mathrm{C}$ (Figure $4 \mathrm{c}$ ). The related activation energies (Figure 4d) are $0.69-0.78 \mathrm{eV}$, which are found to be lower at higher $p C O$ in this region, suggesting a different dominant mechanism under these conditions. Effluent gas QMS analysis indicated that steady-state rates of $\mathrm{H}_{2}$ and $\mathrm{CO}_{2}$ production (Figure 4e) increased with $p C O$ following distinctly separate order dependencies.

Based upon the above observations, the following mechanism is proposed. The appearance of $\mathrm{CO}_{2}$ may be explained via Reaction 7, in which a $\mathrm{CO}$ molecules combines with a lattice oxygen and two mobile electron holes to generate $\mathrm{CO}_{2}$ and an oxygen vacancy site:

$$
\mathrm{CO}+\mathrm{O}_{O}^{X}+2 h^{\bullet} \leftrightarrow \mathrm{CO}_{2}+V_{O}^{\bullet \bullet}
$$

The appearance of $\mathrm{H}_{2}$ may then be explained using a pair of established electrochemical reactions from the literature [48]. In the presence of humidified CO, Reaction 5 may be assumed 
to occur, generating hydroxyl ions from lattice oxygen and vacancies (consumed and/or generated via equilibration of Reaction 7). Secondly, literature has established that when introducing $\mathrm{H}_{2}$ into proton conductors, protons may be reversibly expressed in a hydroxide form [48], thus the reverse of this reaction (Reaction 8) may be assumed to occur such that gaseous hydrogen may equilibrate with hydroxyl ions within the proton conductor:

$$
2 \mathrm{OH}_{O}^{\bullet} \leftrightarrow \mathrm{H}_{2}+2 \mathrm{O}_{O}^{X}+2 h^{\bullet}
$$

Therefore, by combining Reaction 5 and Reaction 8, one may expect gaseous $\mathrm{H}_{2} \mathrm{O}$ molecules to react with oxygen vacancies to create hydrogen and electron holes (Reaction $5+8$ ):

$$
\mathrm{H}_{2} \mathrm{O}+\mathrm{V}_{O}^{\bullet \bullet} \leftrightarrow \mathrm{H}_{2}+\mathrm{O}_{O}^{X}+2 h^{\bullet}
$$

The introduction of $\mathrm{CO}$ facilitates Reaction $5+8$ by generating sufficient oxygen vacancies via Reaction 7. From the resulting mechanism (Reactions 5, 7, 8), increasing electron hole concentration with $p C O$ may be expected if $p C O<p H_{2} \mathrm{O}$, as the presence of $\mathrm{CO}$ promotes $\mathrm{H}_{2} \mathrm{O}$ electrolysis in turn contributing to a positive-order dependence of electrical conductivity upon $p C O$. Once $p C O$ is increased sufficiently for the system to be considered saturated with oxygen vacancies, Reaction 7 may be expected to be dominate such that decreasing electron hole concentration with $p C O$ would result in a negative-order dependence of electrical conductivity upon $p C O$. The above mechanism combines to yield the water-gas-shift overall reaction which is experimentally confirmed via co-generation of $\mathrm{CO}_{2}$ and $\mathrm{H}_{2}$ from humid $\mathrm{CO}$ environment.

$$
\mathrm{CO}+\mathrm{H}_{2} \mathrm{O} \leftrightarrow \mathrm{CO}_{2}+\mathrm{H}_{2}
$$




\subsubsection{Humidified $\mathrm{H}_{2}$}

Impedance spectra obtained under humidified $\mathrm{H}_{2} / \mathrm{Ar}$ environment at both $800^{\circ} \mathrm{C}$ (Figure 5a) and $600^{\circ} \mathrm{C}$ (Figure 5b) did not present the high-frequency inductance tail, which was observed for most of the previous gas environments. The high-frequency inductance tail was attributed to the long lead $(0.5 \mathrm{~mm}$ diameter and $30 \mathrm{~cm}$ length) and clearly observed especially under either high temperatures or non-reducing environments. Additionally, the left-most semicircle associated with grain-boundary transport was seen to be significantly larger than that observed under $\mathrm{H}_{2} \mathrm{O} / \mathrm{Ar}$ and humidified $\mathrm{CO} / \mathrm{Ar}$ environments. Surface reaction was observed at both temperatures due to the presence of low-frequency tail/arc. Electrical conductivity is found to increase mildly (Figure 5c) with $\mathrm{H}_{2}$ partial pressure $\left(\mathrm{pH}_{2}\right)$ under constant $\mathrm{H}_{2} \mathrm{O}$ partial pressure $\left(\mathrm{pH}_{2} \mathrm{O}\right)$ with a power-law order $\theta .040 .11-0.13$ at $700-800^{\circ} \mathrm{C}$. At $600-650^{\circ} \mathrm{C}$, the transient conductivity responded very slowly to environment change ( $\left.T, \mathrm{pH}_{2}\right)$, especially when $\mathrm{pH}_{2} \leqslant$ $0.05 \mathrm{~atm}$, indicating temperature is the rate limiting factor. Activation energies are calculated to be $0.82-0.92 \mathrm{eV}$ (Figure 5d), indicating a more reducing environment would contribute to a higher activation energy. The QMS measurement confirms initial consumption of hydrogen by the button cell upon introduction of moist $\mathrm{H}_{2}$.

Most acceptor-doped perovskites are unsuitable as p-type semi-conductors under reducing conditions, owing to the rapid drop of p-type electronic conductivity with decreasing oxygen activity. [47] However, materials have been shown to exhibit n-type semi-conduction under reducing conditions despite the suppression of free electron concentration created by acceptor doping [47]. Thus, the observed electrochemical behavior of the Fe-doped perovskite under humidified $\mathrm{H}_{2} / \mathrm{Ar}$ may be explained by two n-type semi-conduction mechanisms: 


$$
\begin{gathered}
H_{2}+2 O_{O}^{X} \leftrightarrow 2 O H_{O}^{\bullet}+2 e^{\prime} \\
H_{2}+O_{O}^{X} \leftrightarrow H_{2} O+V_{O}^{\bullet \bullet}+2 e^{\prime}
\end{gathered}
$$

The former mechanism described by Reaction 12 shows the introduction of humidified hydrogen into the lattice of the material would generate hydroxyl ions $\left(\mathrm{OH}_{O}^{\bullet}\right)$, which is formed by the combination of an interstitial proton associating strongly with an oxygen ion in its neighborhood. This mechanism would lead to protonic as well as electronic conductivity, which has been observed in other acceptor-doped barium zirconates capable of hydrogen permeation [30]. Alternatively, increasing n-type conductivity with $\mathrm{pH}_{2}$ may occur due to oxygen abstraction (Reaction 13), in which a hydrogen molecule combines with a lattice oxygen atom to form a water molecule and leave an oxygen vacancy site; however this mechanism is suspect as the reverse was not observed under variable $\mathrm{H}_{2} \mathrm{O}$ exposure. Interestingly, the observed activation energy under humidified hydrogen $(0.82-0.92 \mathrm{eV})$ is significantly greater than that observed under oxygen-acceptor behavior $\left(E_{a}=\sim 0.16-0.18 \mathrm{eV}\right)$ in dry oxygen exposure [32].

\subsubsection{Dry $\mathrm{O}_{2}$}

Dry $\mathrm{O}_{2}$ exposure ( $2^{\text {nd }} \mathrm{O}_{2}$ exposure) was applied upon completing the above cycle of dry $\mathrm{O}_{2}$, dry $\mathrm{CO}_{2}, \mathrm{H}_{2} \mathrm{O}$, humidified $\mathrm{CO}$, and humidified $\mathrm{H}_{2}$ exposures, aiming to explore the reversible performance and recovery potential of the BZF10 cell in comparison to the $1^{\text {st }} \mathrm{O}_{2}$ exposure result [32]. Nyquist plot of the reduced BZF10 material under dry $\mathrm{O}_{2} / \mathrm{Ar}$ (Figure 6a) shows negligible grain boundary resistance due to the absence of the mid-frequency semi-circle. Power-law dependence of the electrical conductivity on $\mathrm{O}_{2}$ partial pressure $\left(\mathrm{pO}_{2}\right)$ presented in 
Figure $6 \mathrm{~b}$ is shown to be in better agreement with the expected $+1 / 4$-order dependence corresponding to p-type semi-conduction behavior (Reaction 14) than prior to reducing gas exposure, while a $\sim 85 \%$ reduction in electrical conductivity is also observed. Figure $6 \mathrm{c}$ presents the semi-log plots of $\sigma T$ verses 1000/T. The activation energy of BZF10 under this $\mathrm{O}_{2}$ exposure is in the range of $0.31-0.36 \mathrm{eV}$ at $600-800^{\circ} \mathrm{C}$, which is almost twice as large as that of the $1^{\text {st }} \mathrm{O}_{2}$ exposure (0.16-0.18 eV).

$$
\frac{1}{2} O_{2}+V_{o}^{\bullet \bullet} \leftrightarrow O_{o}^{X}+2 h^{\bullet}
$$

Figure 7 shows pictures of the $13 \mathrm{~mm}$ button cell before and after testing, confirming the absence of any visible cracks, defects or degradation as a result of the above exposures at 600$800^{\circ} \mathrm{C}$, which indicates there is no disintegration or loss of mechanical stability during the whole button cell test. The total time on-stream for the pellet was $\sim 1080$ hours over the cycle of dry oxidizing, humidified inert, humidified reducing and dry oxidizing environments. Thus, this material is found to be mechanically stable over a range of both oxidizing and reducing gas environments associated with solid-oxide electrolytic cell (SOEC) and solid-oxide reversible fuel cell (SORFC) operations.

These observations suggest a subtle structure change during the above sequence of oxidizing and reducing gas exposures which introduces additional barriers to mobile charge species transport, leading to the observed conductivity degradation at $600-800^{\circ} \mathrm{C}$. Material analysis (synchrotron XRD, TEM, STEM-XEDS, etc.) of the BZF10 pellet used in all gases exposure is proposed to verify the final phase composition and reveal the nature of conductivity degradation. 


\subsection{Synchrotron XRD for the used pellet}

Figure 8 presents the high-resolution XRD pattern obtained from the used BZF10 pellet (Figure 7b), which denotes the BZF10 pellet used in all gases exposure $\left(\mathrm{O}_{2}, \mathrm{CO}_{2}, \mathrm{H}_{2} \mathrm{O}, \mathrm{CO}, \mathrm{H}_{2}\right.$, $\mathrm{O}_{2}$ ), and the as-sintered BZF10 pellet (Figure 7a), respectively. A detailed analysis of the XRD pattern of the as-sintered sample (Figure 8b) was reported elsewhere. [32] All the primary peaks from the reduced pellet sample (Figure 8a) could be indexed into a cubic perovskite phase structure with a lattice parameter of $4.19 \AA$, which is in agreement with that of the as-sintered sample (4.19 $\AA$ ). The low-angle XRD data in Figure 8a is used to identify the minor features (secondary phases) in the material. Table 1 presents the d-spacing values which could not be indexed to the primary cubic phase. Those secondary phases match with patterns reported for materials from the Ba-O, Zr-O, Fe-O and Ba-Fe-O systems in the JCPDS Set-Cards. All the matched d-spacing values and the related space groups are presented in Table 1 for phase identification. All the secondary features are identified as a combined $\mathrm{BaO}, \mathrm{ZrO}_{2}$ and $\mathrm{BaFeO}_{3-\mathrm{x}}$ phases, while their low concentrations confirm that the material remained in a relatively pure perovskite phase. In comparison to the secondary phases revealed in the as-sintered sample [32], the high temperature wet reducing atmospheres exposure did not introduce new phase structure or increase the existed minor phase intensity, which indicates an overall chemical stability of the material under both oxidizing carbonaceous and reducing carbonaceous and non-carbonaceous environments.

\subsection{TEM, diffraction pattern, EDS for used pellet}


The TEM images and their corresponding diffraction pattern data of the cross-section area of the used pellet are given in Figure 9a-d. Especially after humidified reducing gases exposure at $600-800^{\circ} \mathrm{C}$, the grains and grain boundaries (Figure 9a) remained well-defined without any visible structural degradation, indicating promising stability of the crystal structure of the $\mathrm{Ba}-\mathrm{Zr}-\mathrm{Fe}-\mathrm{O}$ system under wet reductive atmosphere. The size of the polycrystalline grains after reduction was 0.3-1.0 $\mu \mathrm{m}$ (average $\sim 0.7 \mu \mathrm{m}$ ), which was consistent with the grain size of the as-sintered pellet. Myriad cracks, initially formed during the ion-milling process, were still observed inside the grains without any significant growth during the reduction process and no mesh areas were created alongside the intergranular region, both of which indicate that negligible hydrolysis of BZF10 during wet reducing gases exposure at $600-800^{\circ} \mathrm{C}$. In a high magnification image of a specific grain (Figure 9c), well-defined grain boundaries were observed, while visible defects and cracks (attributing to sample preparation) indicates a brittle structure within the grain. High resolution TEM image (Figure 9d) presents multiple parallel well-structured $(1,0,0)$ planes confirmed by the calculated d-spacing $(\sim 4.20 \AA)$. A detailed analysis of diffraction pattern (Figure 9b) is given in Table 2. The polycrystalline structure of this reduced pellet was further confirmed by multiple concentric Debye rings observed in the diffraction pattern. All calculated d-spacings data based upon this sample slightly shifted to higher values, but were still in good match with the primary phase and secondary phases identified by synchrotron XRD technique. The diffraction pattern data did not reveal any additional secondary phase formation through wet reduction while observed d-spacings indicated the presence of the original primary BZF10 phase along with minimal $\mathrm{BaO}, \mathrm{ZrO}_{2}$ and $\mathrm{BaFeO}_{3-\delta}$.

The used pellet specimen was chemically and elementally mapped by STEM-XEDS for $\mathrm{Ba}, \mathrm{Zr}$ and $\mathrm{Fe}$ (Figure 10). A specific grain and surrounding intergranular regions were chosen 
for elemental mapping to allow simultaneous mapping of representative grain and grain boundary regions. Ba was uniformly distributed throughout the material without any tendency of segregation, with the exception of a small localized intergranular area where Ba was absent (upper left part of Ba map). Zr primarily located within the grains, and comparison with previously reported STEM-XEDS of the as-sintered material indicates a great segregation of $\mathrm{Zr}$ in favor of grain regions after reduction. Fe signals increased within the grain boundaries while decreasing in the grains, as compared to the as-sintered sample, providing strong evidence that $\mathrm{Fe}$ had full segregated into the localized regions along the grain boundaries during reduction. These observations suggest that upon reduction of the as-sintered pellet Ba remains in both grain and grain boundaries in the formula of $\mathrm{BaO}$ while $\mathrm{Zr}$ diffuses into the grains to form $\mathrm{ZrO}_{2}$ and $\mathrm{Fe}$ segregates in the form of $\mathrm{FeO}_{\mathrm{x}}$ in regions where $\mathrm{Zr}$ amount is the lowest (intergranular regions) and where $\mathrm{Ba}$ is absent (upper left part of the map). This observation confirms that the grains are primarily comprised of pure barium zirconate $\left(\mathrm{BaZrO}_{3}\right)$ after reduction. In the grain boundary regions, $\mathrm{FeO}_{\mathrm{x}}$ is present either in a $\mathrm{Ba}$-lack region or alongside $\mathrm{BaO}$ forming a $\mathrm{BaFeO}_{3-\delta}$ phase. Therefore, the intergranular phases may be identified as $\mathrm{FeO}_{\mathrm{x}} / \mathrm{BaFeO}_{3-\delta}$, but the newly formed Fe-rich phase does not dominate the total electrical conductivity from dry oxidizing to wet reducing atmospheres.

Although the material analysis of the used sample via synchrotron XRD, TEM, diffraction pattern and STEM-XEDS all shows great consistency in phase structure with that of the as-sintered sample prior to all tests, subtle changes in minor quantities are also observed in this study. The chemical maps of $\mathrm{Zr}$ and Fe both indicate an irreversible elemental transportation during the high-temperature reducing gas exposure, which affects the minor phase composition and appears to be the primary reason of the conductivity degradation. The complete segregation 
of Fe in the intergranular region further reduced the dopant concentration inside the grains, which closely corresponds to the conductivity degradation by decreasing oxygen vacancy concentration.

\section{Conclusions}

This work presents the first investigation of a novel mixed conducting $\mathrm{BaZr}_{0.9} \mathrm{Fe}_{0.1} \mathrm{O}_{3-\delta}$ perovskite (BZF10) in terms of electrochemical, catalytic properties and material characterization over a complete span of gas environments expected for SOEC or SORFC operation. This electroceramic material is found to exhibit both mixed ionic-electronic conduction under oxidizing conditions and mixed protonic-electronic conduction under humidified reducing conditions. Under dry $\mathrm{O}_{2}$ conditions, this material displays p-type semiconduction behavior, suggesting oxygen-acceptor activity via reaction with oxygen vacancies. Upon exposure to dry $\mathrm{CO}_{2}$ atmosphere, the material shows catalytic activity towards $\mathrm{CO}_{2}$ reduction to $\mathrm{CO}$ and $\mathrm{O}_{2}$ which is attributed to an intermediate carbonate ion formation on the cell surface. Exposure to moisture inert suggests only mild interaction with steam, indicating either equivalent hydroxyl-ion and oxygen-vacancy conductivity or negligible activity for steam hydrolysis in the absence of co-reactants. Under moist CO environment, a complex conduction mechanism is displayed alongside significant rates of water-gas-shift reaction coinciding with an initial increase in electrical conductivity at low $p C O$ and subsequent decrease in electrical conductivity at high $p C O$. Exposure to humidified $\mathrm{H}_{2}$ results in increase in conductivity with $\mathrm{pH}_{2}$, indicating n-type semi-conduction under this gas environment. Upon completion of $>1,000$ hours of continuous exposure to a range of oxidizing and reducing gas environments, physical 
inspection of the BZF10 electrochemical cell indicated negligible chemical or mechanical degradation. The pellet used in all gases exposure experiments was characterized using synchrotron XRD, TEM, diffraction patterns, and STEM-XEDS, indicating stable phase composition and stable grain structure within the pellet. Elemental maps via XEDS indicate Fe segregation fully into the intergranular region, which closely corresponds to the conductivity drop after all gases test. This unique combination of electrical conduction, catalytic activity and long-term material stability makes this material a promising candidate for solid-oxide electrolytic cells (SOEC) and solid-oxide reversible fuel cells (SORFC) applications.

\section{Acknowledgement}

Acknowledgement is made to the Advanced Photon Source, Argonne National Lab for providing free-of-charge synchrotron XRD analysis. This work was supported in part through the National Science Foundation Process and Reaction Engineering Program (Award \#1319142). Additional financial support was provided by the Artie McFerrin Department of Chemical Engineering.

\section{References}

[1] R. Moos, Int. J. Appl. Ceram. Technol. 2 (2005) 401-413.

[2] V. Esposito, E. Traversa, J. Am. Ceram. Soc. 91 (2008) 1037-1051.

[3] H. Tanaka, M. Taniguchi, M. Uenishi, N. Kajita, I. Tan, Y. Nishihata, J. Mizuki, K. Narita, M. Kimura, K. Kaneko, Angew. Chem. 118 (2006) 6144-6148.

[4] J.C. Ruiz-Morales, J. Canales-Vázquez, B. Ballesteros-Pérez, J. Peña-Martínez, D. MarreroLópez, J.T.S. Irvine, P. Núñez, J. Eur. Ceram. Soc. 27 (2007) 4223-4227. 
[5] H.L. Tuller, Sens. Actuators B-Chem. 187 (2013) 106-110.

[6] J. Sunarso, S. Baumann, J.M. Serra, W.A. Meulenberg, S. Liu, Y.S. Lin, J.C. Diniz da Costa, J. Membr. Sci. 320 (2008) 13-41.

[7] A. Leo, S. Liu, J.C. Diniz da Costa, Int. J. Greenh. Gas Con. 3 (2009) 357-367.

[8] W. Yang, H. Wang, X. Zhu, L. Lin, Top. Catal. 35 (2005) 155-167.

[9] A. Löfberg, H. Bodet, C. Pirovano, C. Steil, R.N. Vannier, E. Bordes-Richard, Catal. Today 117 (2006) 168-173.

[10] S.H. Jensen, P.H. Larsen, M. Mogensen, Int. J. Hydrogen Energ. 32 (2007) 3253-3257.

[11] Z. Zhan, W. Kobsiriphat, J.R. Wilson, M. Pillai, I. Kim, S.A. Barnett, Energ. Fuels 23 (2009) 3089-3096.

[12] P. Kim-Lohsoontorn, J. Bae, J. Power Sources 196 (2011) 7161-7168.

[13] M. Mogensen, S.H. Jensen, A. Hauch, I. Chorkendorff, T. Jacobsen, Ceram. Eng. Sci. Proc. 28 (2008) 91-101.

[14] N.Q. Minh, M.B. Mogensen, Electrochem. Soc. Interface 22 (2013) 55-62.

[15] M.A. Laguna-Bercero, J.A. Kilner, S.J. Skinner, Solid State Ionics 192 (2011) 501-504.

[16] D.M. Bierschenk, J.R. Wilson, S.A. Barnett, Energy Environ. Sci. 4 (2011) 944-951.

[17] G. Schiller, A. Ansar, M. Lang, O. Patz, J. Appl. Electrochem. 39 (2009) 293-301.

[18] M. Ni, M.K.H. Leung, D.Y.C. Leung, Int. J. Hydrogen Energ. 33 (2008) 2337-2354.

[19] A. Brisse, J. Schefold, M. Zahid, Int. J. Hydrogen Energ. 33 (2008) 5375-5382.

[20] J.D. Holladay, J. Hu, D.L. King, Y. Wang, Catal. Today 139 (2009) 244-260.

[21] S.H. Jensen, X. Sun, S.D. Ebbesen, R. Knibbe, M. Mogensen, Int. J. Hydrogen Energ. 35 (2010) 9544-9549.

[22] L. Adijanto, V.B. Padmanabhan, R. Küngas, R.J. Gorte, J.M. Vohs, J. Mater. Chem. 22 (2012) 11396-11402.

[23] X. Li, H. Zhao, F. Gao, Z. Zhu, N. Chen, W. Shen, Solid State Ionics 179 (2008) 15881592.

[24] J.Q. Li, P. Xiao, J. Eur. Ceram. Soc. 21 (2001) 659-668.

[25] J. Mizusaki, T. Saito, H. Tagawa, J. Electrochem. Soc. 143 (1996) 3065-3073.

[26] S.J. Skinner, Fuel Cells Bull. 33 (2001) 6-12.

[27] H.J. Hwang, J.W. Moon, S. Lee, E.A. Lee, J. Power Sources 145 (2005) 243-248. 
[28] H.J.M. Bouwmeester, Catal. Today 82 (2003) 141-150.

[29] C.Y. Tsai, A.G. Dixon, W.R. Moser, Y.H. Ma, AIChE J. 43 (1997) 2741-2750.

[30] A. Suresh, J. Basu, C.B. Carter, N. Sammes, B.A. Wilhite, J. Mater. Sci. 45 (2010) 32153227.

[31] J. Basu, A. Suresh, C.B. Carter, B.A. Wilhite, J. Eur. Ceram. Soc. 31 (2011) 1421-1429.

[32] H. Zhang, A. Suresh, C.B. Carter, B.A. Wilhite, Solid State Ionics 266 (2014) 58-67.

[33] H. Song, L. Zhang, R.B. Watson, Catal. Today 129 (2007) 346-354.

[34] D.R. Sahoo, S. Vajpai, S. Patel, K.K. Pant, Chem. Eng. J. 125 (2007) 139-147.

[35] E. Ruckenstein, H.Y. Wang, Catal. Lett. 73 (2001) 99-105.

[36] N.E. Tsakoumis, M. Rønning, Ø. Borg, E.R.A. Holmen, Catal. Today 154 (2010) 162-182.

[37] J. Clarke, M.E. Dry, J.J. Montano and W.J. van Zyl. Trans. Faraday Soc. 57 (1961) 22392246.

[38] R. Rudham, F.S. Stone. Chemisorption: Proceedings of Chemical Society Symposium (1956) 205-217.

[39] D.P. Fagg, V.V. Kharton, A.V. Kovalevsky, A.P. Viskup, E.N. Naumovich, J.R. Frade, J. Eur. Ceram. Soc. 21 (2001) 1831-1835.

[40] T. Ishihara, T. Yamada, H. Arikawa, H. Nishiguchi, Y. Takita, Solid State Ionics 135 (2000) 631-636.

[41] F. Kröger, H. Vink, Academic Press 3 (1956) 307-435.

[42] J. Ortiz-Landeros, T. Norton, Y.S. Lin, Chem. Eng. Sci. 104 (2013) 891-898.

[43] Z. Rui, M. Anderson, Y.S. Lin, Y. Li, J. Membr. Sci. 345 (2009) 110-118.

[44] X. Qi, Y.S. Lin, Solid State Ionics 130 (2000) 149-156.

[45] K.D. Kreuer, Chem. Mater. 8 (1996) 610-641.

[46] S.-J. Song, E.D. Wachsman, J. Rhodes, S.E. Dorris, U. Balachandran, Solid State Ionics 167 (2004) 99-105.

[47] T. Norby, Solid State Ionics 125 (1999) 1-11.

[48] X. Qi, Y.S. Lin, Solid State Ionics 120 (1999) 85-93. 


\section{List of Figures}

Figure 1: Schematic of the single-chamber apparatus for combined electrochemical and catalytic analysis.

Figure 2: (a). EIS spectra obtained upon equilibration of BZF10 with dry $\mathrm{CO}_{2} / \mathrm{Ar}$ exposure at $800^{\circ} \mathrm{C}$; (b). EIS spectra obtained upon equilibration of BZF10 with dry $\mathrm{CO}_{2} / \mathrm{Ar}$ exposure at $600^{\circ} \mathrm{C}$; (c). Log-log plots of electrical conductivity verse $\mathrm{CO}_{2}$ partial pressures $\left(p C \mathrm{O}_{2}\right)$ at $600-800^{\circ} \mathrm{C}$; (d). Semi-log plots of $\sigma T$ verse $1000 / T$ under $\mathrm{CO}_{2}$ exposure; (e). Log-log plots of reaction rate verse $p C \mathrm{O}_{2}$ at $600-800^{\circ} \mathrm{C}$.

Figure 3: (a). EIS spectra obtained upon equilibration of BZF10 with $\mathrm{H}_{2} \mathrm{O} / \mathrm{Ar}$ exposure at $800^{\circ} \mathrm{C}$ and $600^{\circ} \mathrm{C}$; (b). Log-log plots of electrical conductivity verse $\mathrm{H}_{2} \mathrm{O}$ partial pressures $\left(p \mathrm{H}_{2} \mathrm{O}\right)$ at $600-800^{\circ} \mathrm{C}$; (c). Semi-log plots of $\sigma T$ verse $1000 / T$ under $\mathrm{H}_{2} \mathrm{O}$ exposure.

Figure 4: (a). EIS spectra obtained upon equilibration of BZF10 with $\mathrm{CO} / \mathrm{H}_{2} \mathrm{O} / \mathrm{Ar}$ exposure at $800^{\circ} \mathrm{C}$; (b). EIS spectra obtained upon equilibration of BZF10 with $\mathrm{CO} / \mathrm{H}_{2} \mathrm{O} / \mathrm{Ar}$ exposure at $600^{\circ} \mathrm{C}$; (c). Log-log plots of electrical conductivity verse $\mathrm{CO}$ partial pressures $(p C O)$ at $600-800^{\circ} \mathrm{C}$; (d). Semi-log plots of $\sigma T$ verse $1000 / T$ under CO exposure; (e). Log-log plots of $\mathrm{CO}_{2}$ and $\mathrm{H}_{2}$ production rate verse $p C O$ at $600-800^{\circ} \mathrm{C}$; (f). $\mathrm{H}_{2} / \mathrm{CO}_{2}$ selectivity at $600-800^{\circ} \mathrm{C}$.

Figure 5: (a). EIS spectra obtained upon equilibration of BZF10 with $\mathrm{H}_{2} / \mathrm{H}_{2} \mathrm{O} / \mathrm{Ar}$ exposure at $800^{\circ} \mathrm{C}$; (b). EIS spectra obtained upon equilibration of BZF10 with $\mathrm{H}_{2} / \mathrm{H}_{2} \mathrm{O} / \mathrm{Ar}$ exposure at $600^{\circ} \mathrm{C}$; (c). Log-log plots of electrical conductivity verse $\mathrm{H}_{2}$ partial 
pressures $\left(p H_{2}\right)$ at $600-800^{\circ} \mathrm{C}$; (d). Semi-log plots of $\sigma T$ verse $1000 / T$ under $\mathrm{H}_{2}$ exposure.

Figure 6: (a). EIS spectra obtained upon equilibration of BZF10 with dry $\mathrm{O}_{2} / \mathrm{Ar}$ exposure at $800^{\circ} \mathrm{C}$; (b). Log-log plots of electrical conductivity verse $\mathrm{O}_{2}$ partial pressures $\left(p O_{2}\right)$ at $600-800^{\circ} \mathrm{C}$; (c). Semi-log plots of $\sigma T$ verse $1000 / T$ under $\mathrm{O}_{2}$ exposure.

Figure 7: (a). Picture of the as-sintered pellet before all the tests; (b). Picture of the used pellet with porous Pt electrode on the top and blocking Pt electrode in the bottom after all the tests.

Figure 8: Synchrotron XRD patterns of BZF10. (a) used pellet; (b) as-synthesized pellet.

Figure 9: (a). TEM image of the used BZF10 pellet sample; (b). Diffraction pattern obtained from the crystalline grain structures of part (a); (c). High-resolution TEM image of the clear grain boundary; (d). High-resolution TEM image of a specific grain.

Figure 10: STEM-XEDS map obtained from the used pellet sample; (a) SEM image of prepared sample; (b) STEM image of sample with inset elemental maps for $\mathrm{Ba}, \mathrm{Zr}$ and $\mathrm{Fe}$. 


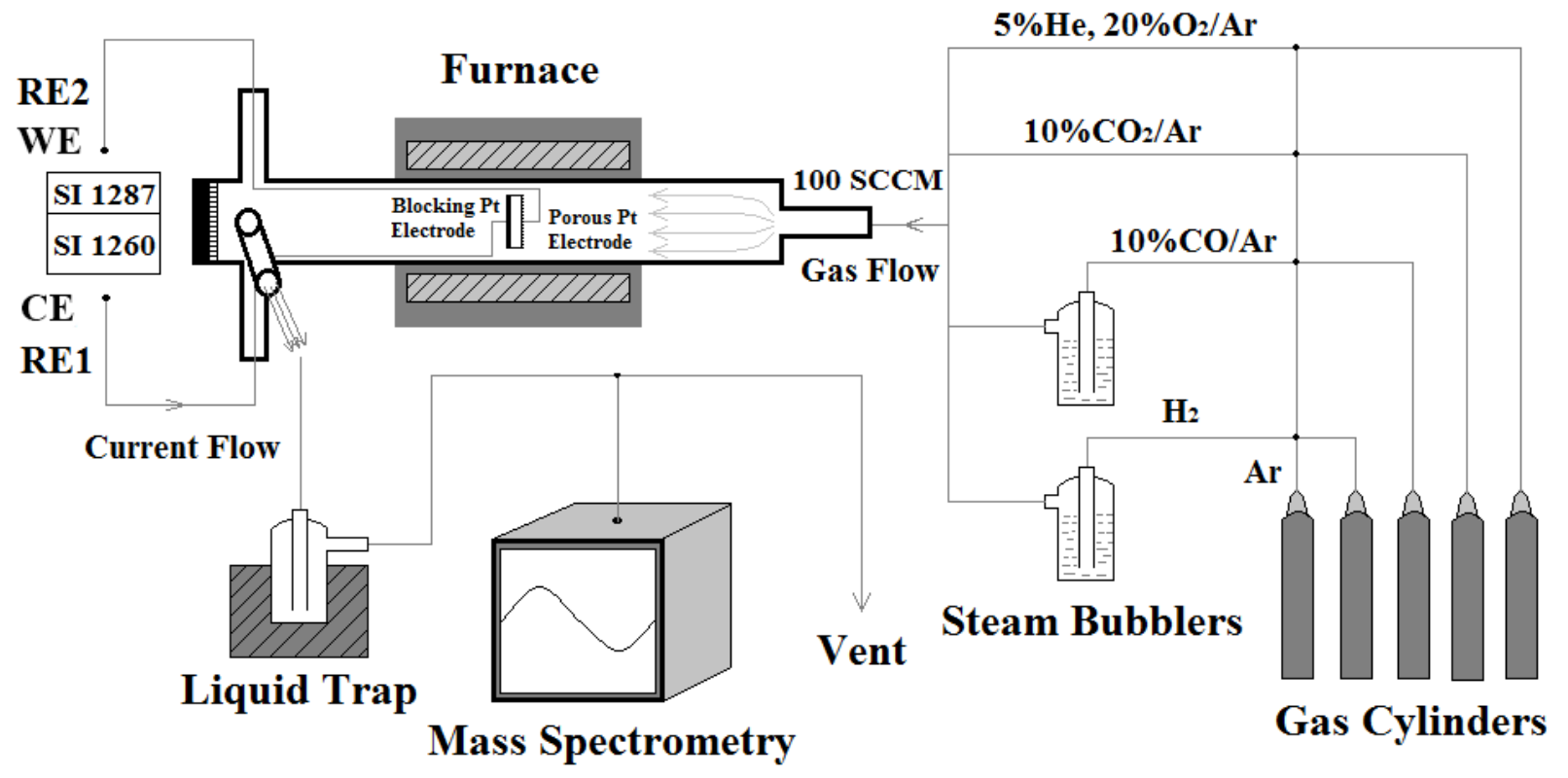

Figure 1 
(a)
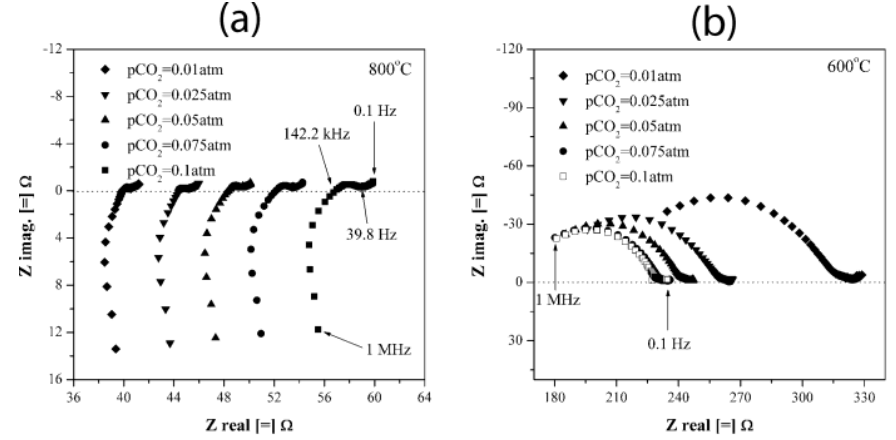

(c)

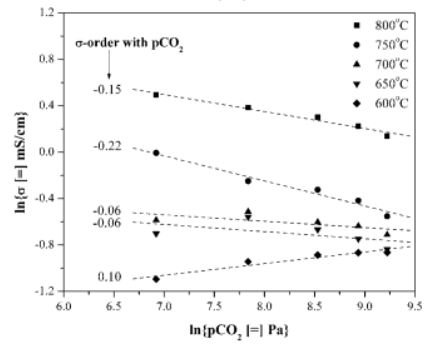

(d)
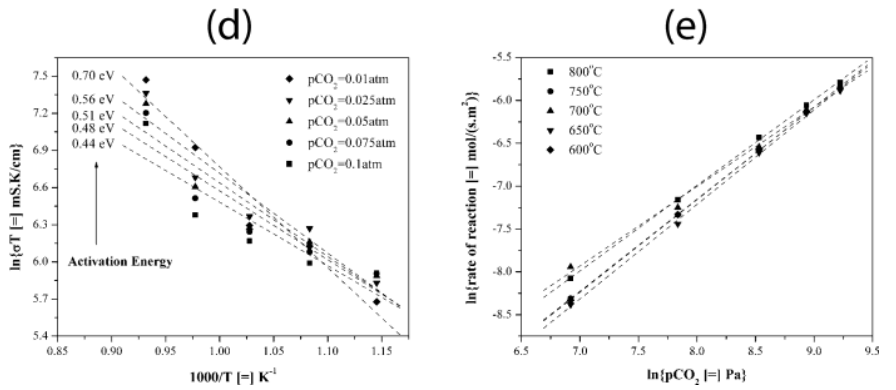

Figure 2 
(a)

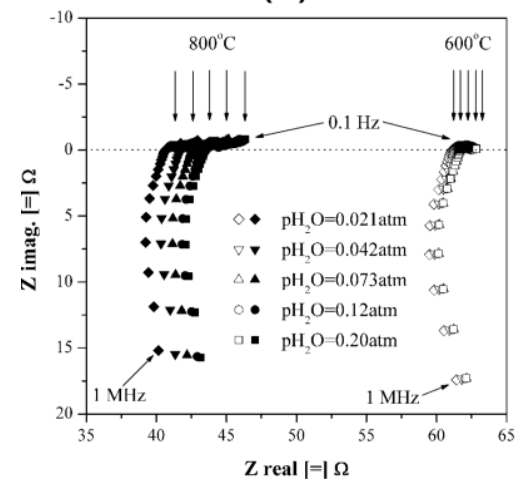

(b)

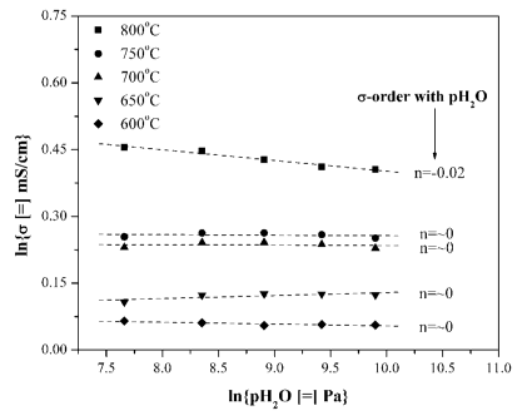

(c)

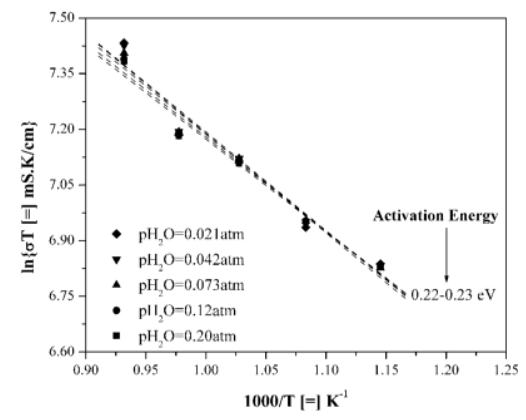

Figure 3 
(a)

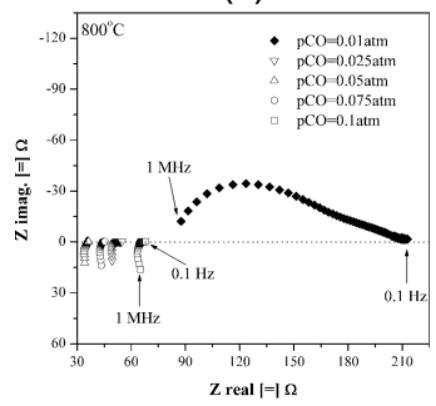

(c)

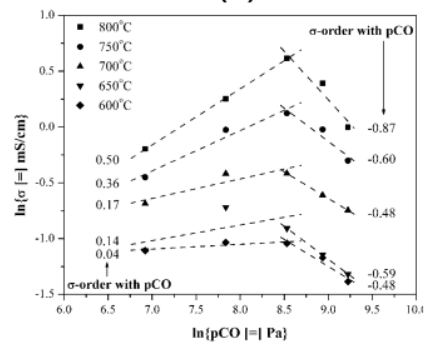

(e)

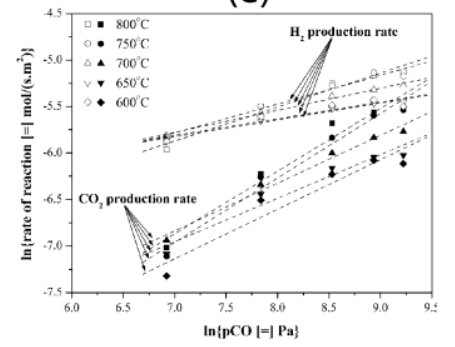

(b)

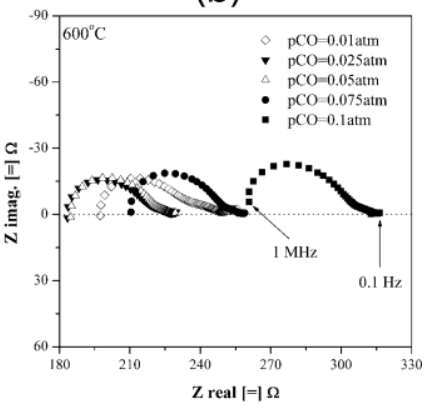

(d)

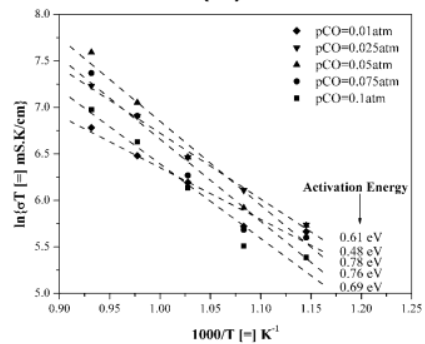

(f)

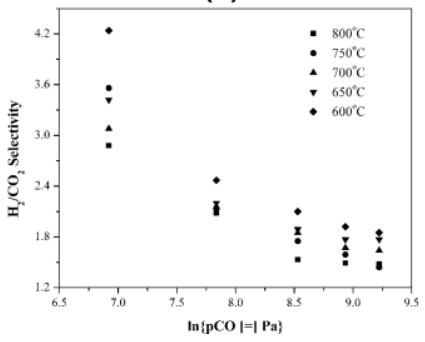

Figure 4 
(a)

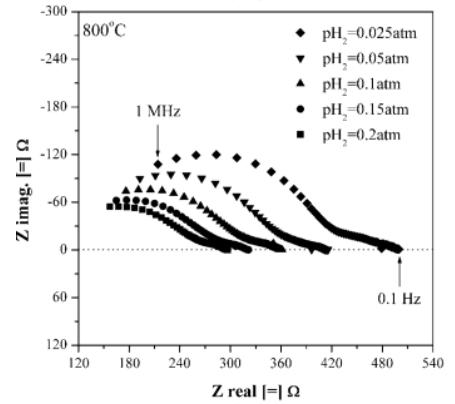

(c)

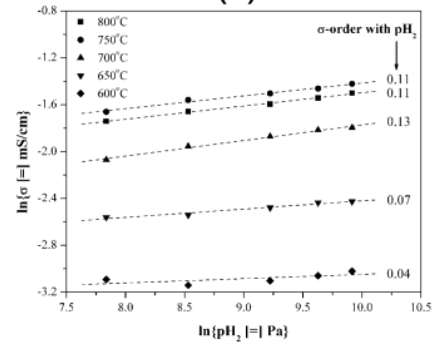

(b)

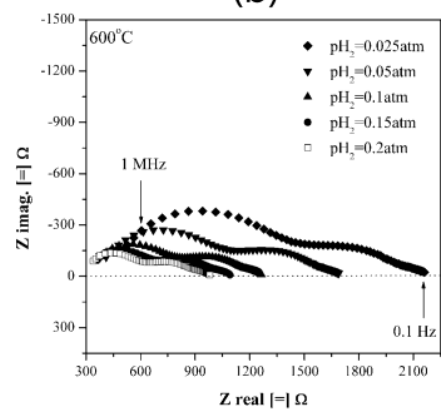

(d)

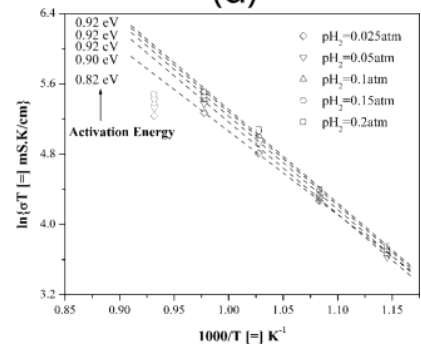

Figure 5 
(a)

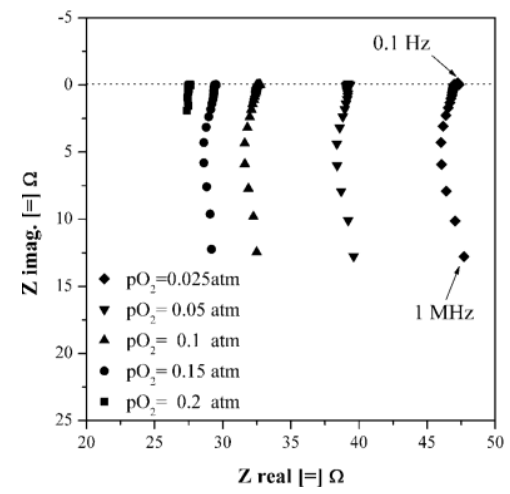

(b)

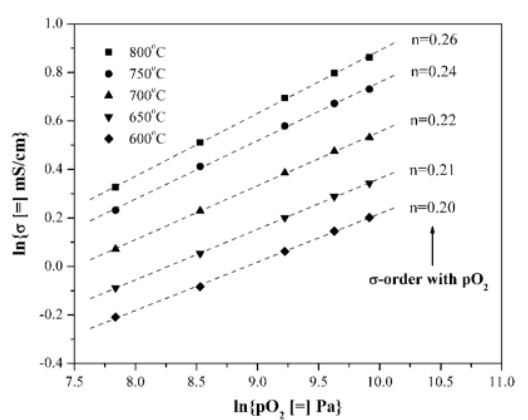

(c)

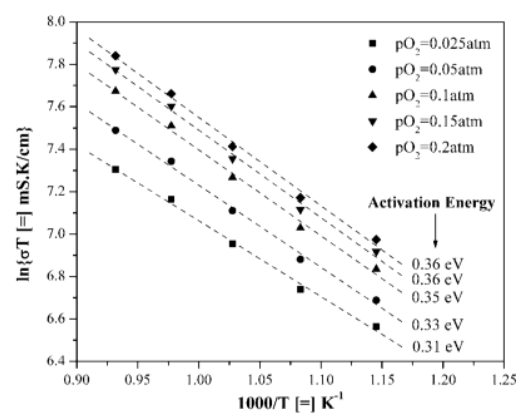

Figure 6 


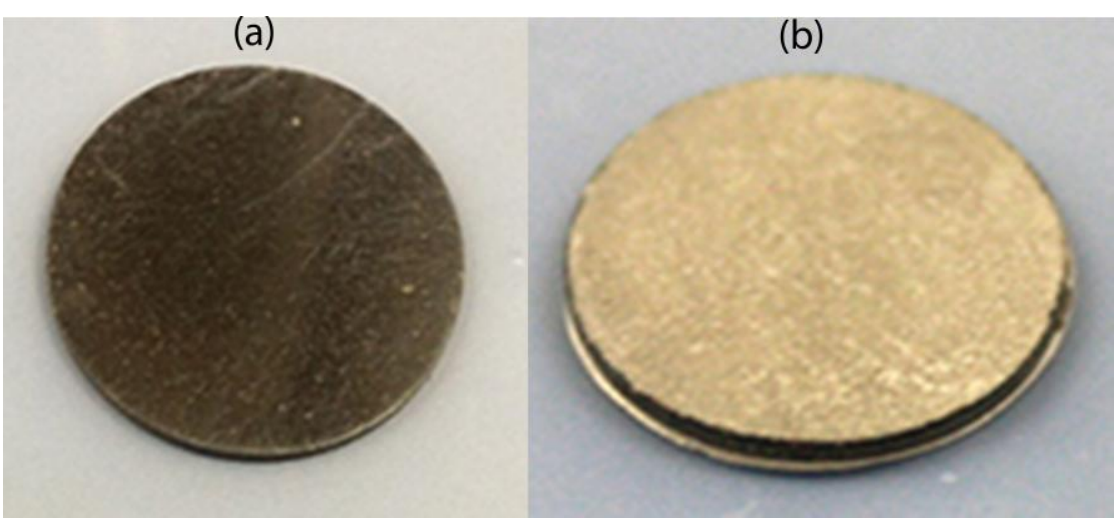

Figure 7 


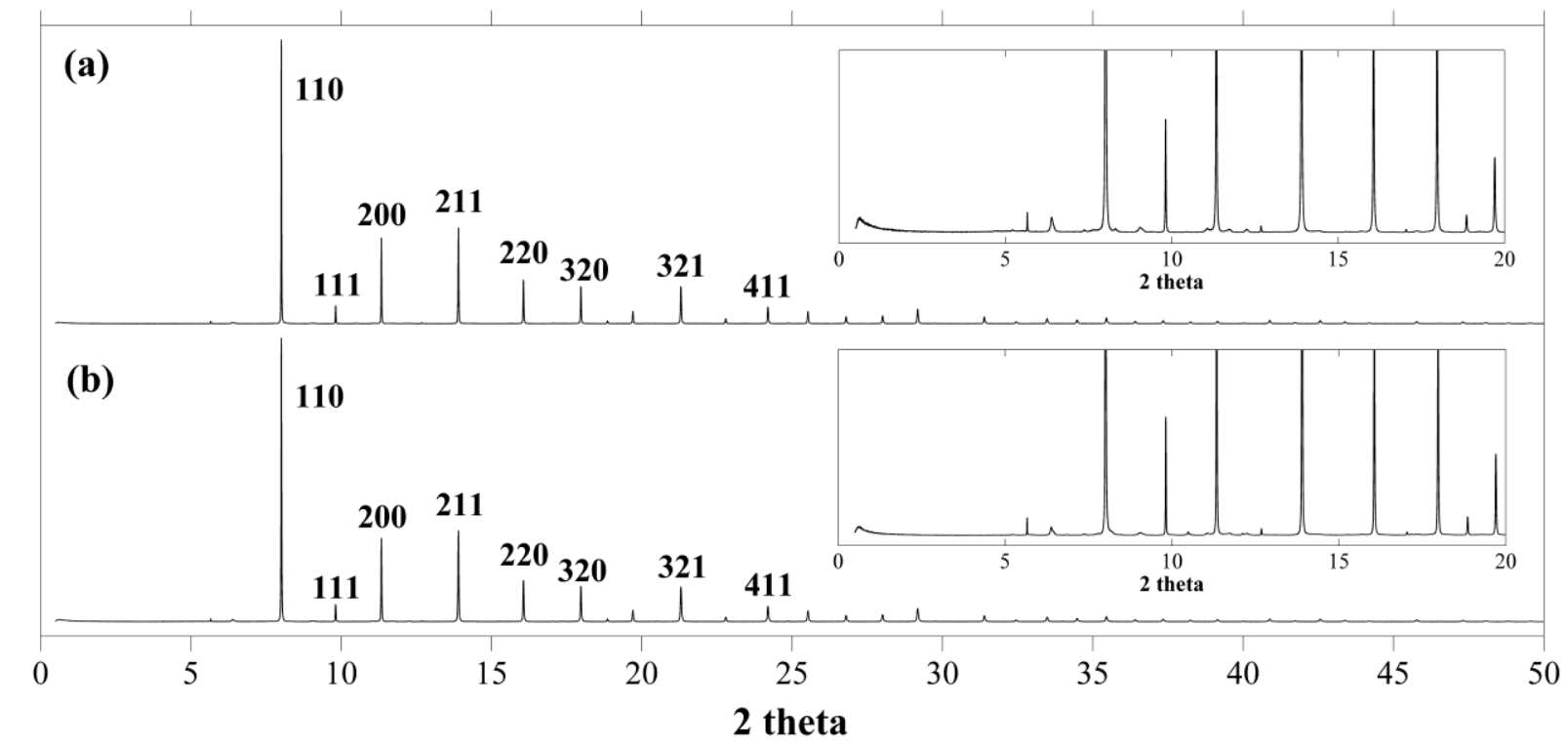

Figure 8 


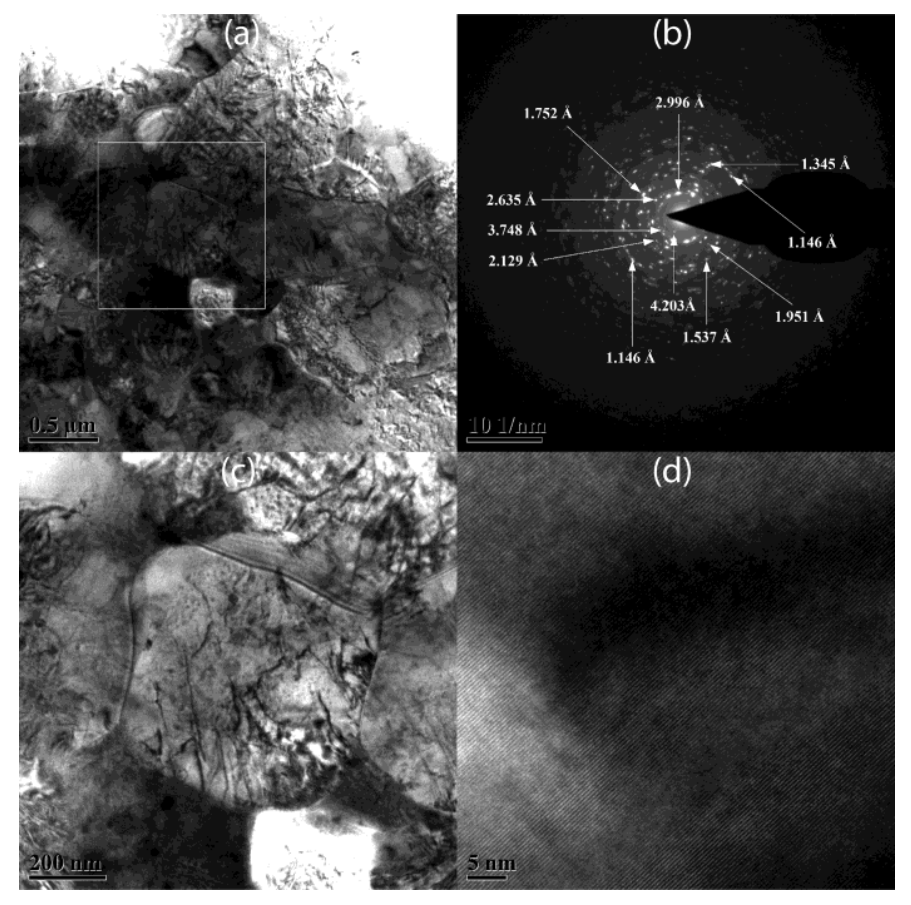

Figure 9 


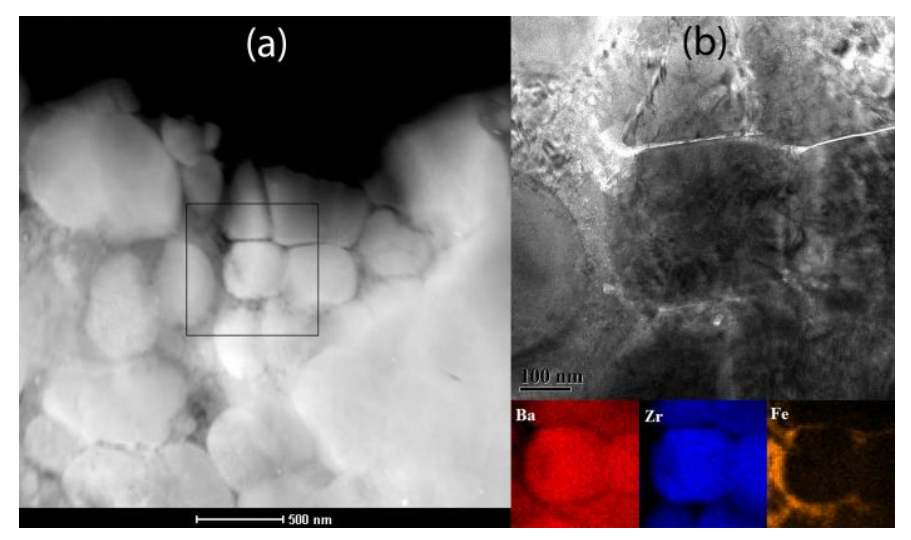

Figure 10 
Table 1: Reported and measured d-spacing values (* denotes low intensity peak) of the BZF10 material upon exposure to $\mathrm{CO}_{2}$, humid $\mathrm{Ar}, \mathrm{CO}$ and $\mathrm{H}_{2}$.

\begin{tabular}{|c|c|c|c|c|c|c|c|c|}
\hline $\begin{array}{l}\text { Observed d-spacings }(\AA) \\
\text { (Secondary phases) }\end{array}$ & 3.719 & 3.220 & 2.627 & 2.265 & 2.149 & 2.028 & 1.960 & 1.935 \\
\hline $\begin{array}{l}\text { Reported d-spacings }(\AA) \\
\mathrm{BaO}(\mathrm{PDF} \# 01-0746)\end{array}$ & & $\begin{array}{l}3.200 \\
(111)\end{array}$ & & & & & $\begin{array}{l}1.950 \\
(220)\end{array}$ & \\
\hline $\begin{array}{l}\text { Reported d-spacings }(\AA) \\
\mathrm{ZrO}_{2}(\mathrm{PDF} \# 65-2357)\end{array}$ & & $\begin{array}{l}3.207 \\
(-111)\end{array}$ & $\begin{array}{l}2.635 \\
(020)\end{array}$ & & & $\begin{array}{l}2.021 \\
(-202)\end{array}$ & & \\
\hline $\begin{array}{l}\text { Reported d-spacings }(\AA) \\
\mathrm{FeO}(\mathrm{PDF} \# 06-0615)\end{array}$ & & & & & $\begin{array}{l}2.153 \\
(200)\end{array}$ & & & \\
\hline $\begin{array}{l}\text { Reported d-spacings }(\AA) \\
\mathrm{Fe}_{2} \mathrm{O}_{3}(\mathrm{PDF} \# 16-0653)\end{array}$ & & $\begin{array}{l}3.240 \\
(022)\end{array}$ & $\begin{array}{l}2.573 \\
(-213)\end{array}$ & & $\begin{array}{l}2.176 \\
(521)\end{array}$ & $\begin{array}{l}2.018 \\
(050)\end{array}$ & $\begin{array}{l}1.973 \\
(-441)\end{array}$ & \\
\hline $\begin{array}{l}\text { Reported d-spacings }(\AA) \\
\mathrm{BaFeO}_{2.9}(\mathrm{PDF} \# 25-0068)\end{array}$ & $\begin{array}{l}3.700 \\
(105)\end{array}$ & & & $\begin{array}{l}2.253 \\
(205)\end{array}$ & $\begin{array}{l}2.099 \\
(207)\end{array}$ & $\begin{array}{l}2.013 \\
(208)\end{array}$ & & \\
\hline $\begin{array}{l}\text { Reported d-spacings }(\AA) \\
\mathrm{BaFeO}_{2.6}(\mathrm{PDF} \# 39-0183)\end{array}$ & $\begin{array}{l}3.680 \\
(003)\end{array}$ & & $\begin{array}{l}2.600 \\
(230)\end{array}$ & $\begin{array}{l}2.270 \\
(134)\end{array}$ & $\begin{array}{l}2.113 \\
(054)\end{array}$ & $\begin{array}{l}2.015 \\
(208)\end{array}$ & $\begin{array}{l}1.977 \\
(073)\end{array}$ & \\
\hline $\begin{array}{l}\text { Reported d-spacings ( } \AA \text { ) } \\
\mathrm{BaFeO}_{3}(\mathrm{PDF} \# 74-0646)\end{array}$ & $\begin{array}{l}3.700 \\
(015)\end{array}$ & & & $\begin{array}{l}2.255 \\
(205)\end{array}$ & $\begin{array}{l}2.098 \\
(027)\end{array}$ & $\begin{array}{l}2.015 \\
(208)\end{array}$ & $\begin{array}{l}1.974 \\
(1013)\end{array}$ & \\
\hline $\begin{array}{l}\text { Reported d-spacings }(\AA) \\
\mathrm{BaFe}_{2} \mathrm{O}_{4}(\mathrm{PDF} \# 25-1191)\end{array}$ & & $\begin{array}{l}3.160 \\
(402)\end{array}$ & $\begin{array}{l}2.590 \\
(701)\end{array}$ & $\begin{array}{l}2.265 \\
(503)\end{array}$ & $\begin{array}{l}2.110 \\
(004)\end{array}$ & $\begin{array}{l}2.051 \\
(422)\end{array}$ & & $\begin{array}{l}1.930 \\
(404)\end{array}$ \\
\hline $\begin{array}{l}\text { Reported d-spacings }(\AA) \\
\mathrm{BaFe}_{2} \mathrm{O}_{4}(\mathrm{PDF} 26-0158)\end{array}$ & & $\begin{array}{l}3.260 \\
(102)\end{array}$ & $\begin{array}{l}2.613 \\
\text { (111) }\end{array}$ & $\begin{array}{l}2.254 \\
(004)\end{array}$ & $\begin{array}{l}2.092 \\
(202)\end{array}$ & $\begin{array}{l}2.033 \\
(104)\end{array}$ & & \\
\hline
\end{tabular}




\begin{tabular}{|c|c|c|c|c|c|c|c|c|}
\hline $\begin{array}{l}\text { Reported d-spacings }(\AA) \\
\mathrm{BaFe}_{2} \mathrm{O}_{4}(\mathrm{PDF} \# 44-0897)\end{array}$ & & $\begin{array}{l}3.203 \\
(102)\end{array}$ & $\begin{array}{l}2.683 \\
(110)\end{array}$ & $\begin{array}{l}2.295 \\
(112)\end{array}$ & & $\begin{array}{l}2.057 \\
(202)\end{array}$ & & \\
\hline $\begin{array}{l}\text { Reported d-spacings }(\AA) \\
\mathrm{Ba}_{2} \mathrm{Fe}_{2} \mathrm{O}_{5}(\mathrm{PDF} \# 39-1296)\end{array}$ & $\begin{array}{c}3.670 \\
(610) \\
*\end{array}$ & $\begin{array}{l}3.210 \\
(231)\end{array}$ & $\begin{array}{c}2.652 \\
(531) \\
*\end{array}$ & $\begin{array}{l}2.270 \\
(541)\end{array}$ & $\begin{array}{c}2.187 \\
(740) \\
*\end{array}$ & $\begin{array}{l}2.068 \\
(802)\end{array}$ & $\begin{array}{c}1.984 \\
(\underline{11} 20) \\
*\end{array}$ & $\begin{array}{c}1.940 \\
(160) \\
*\end{array}$ \\
\hline
\end{tabular}


Table 2: Comparison and analysis of the calculated d-spacings

\begin{tabular}{|c|c|c|c|c|c|}
\hline $\begin{array}{l}\text { Calculated d- } \\
\text { spacing }(\AA) \\
\text { (HRXRD for } \\
\text { BZF10 powder) }\end{array}$ & $\begin{array}{c}\text { Calculated d- } \\
\text { spacing }(\AA) \\
\text { (DP for as-sintered } \\
\text { BZF10 pellet) }\end{array}$ & $\begin{array}{l}\text { Calculated d- } \\
\text { spacing }(\AA) \\
\text { (DP for used } \\
\text { BZF10 pellet) }\end{array}$ & $\begin{array}{c}\text { Reported d- } \\
\text { spacing }(\AA) \\
\left(\mathrm{BaZrO}_{3}\right) \\
\text { PDF\# 06-0399 }\end{array}$ & $\begin{array}{c}\text { Reported d- } \\
\text { spacing }(\AA) \\
\left(\mathrm{BaFeO}_{3}\right) \\
\text { PDF\# 74-0646 }\end{array}$ & $\begin{array}{c}\text { Phase } \\
\text { Identification }\end{array}$ \\
\hline $4.190(100)$ & 4.188 & 4.203 & $4.194(100)$ & $4.030(104)$ & BZF10 \\
\hline 3.712 & 3.727 & 3.748 & -- & $3.700(015)$ & $\mathrm{BaFeO}_{3-\delta}$ \\
\hline $2.964(110)$ & 2.955 & 2.996 & $2.965(110)$ & $2.845(110)$ & BZF10 \\
\hline 2.623 & 2.621 & 2.635 & -- & -- & $\mathrm{ZrO}_{2}$ \\
\hline $2.095(200)$ & 2.096 & 2.129 & $2.097(200)$ & $2.098(027)$ & BZF10 \\
\hline 1.935 & 1.934 & 1.951 & -- & $1.974(10 \underline{13})$ & $\mathrm{BaO}$ \\
\hline $1.711(211)$ & 1.715 & 1.752 & $1.711(211)$ & $1.688(217)$ & BZF10 \\
\hline $1.482(220)$ & 1.480 & 1.537 & $1.482(220)$ & $1.422(220)$ & BZF10 \\
\hline $1.325(310)$ & 1.329 & 1.345 & $1.325(310)$ & $1.293(137)$ & BZF10 \\
\hline $1.120(321)$ & 1.125 & 1.146 & $1.120(321)$ & $1.128(31 \underline{14})$ & BZF10 \\
\hline $0.937(420)$ & 0.940 & 0.955 & $0.937(420)$ & -- & BZF10 \\
\hline
\end{tabular}

